Reprod. Nutr. Dévelop., 1981, 21 (4), 505-512.

\title{
Relative changes in the RNA contents of oocytes and preimplantation embryos of the mouse
}

\author{
par G. P. M. MOORE (1), Sue LINTERN-MOORE, Lisa SCOTT-MURPHY
}

(1) Division of Animal Production, C.S.I.R.O., P.O. Box 239, Blacktown, N.S.W., 2148, Australia.

School of Biological Sciences, Macquarie University, North Ryde, N.S.W., 2113, Australia.

Summary. Changes in Azur B basophilia of isolated oocytes and preimplantation embryos of the mouse have been quantitated cytophotometrically. Components of the nuclei and cytoplasm bound Azur B but most of the dye-binding capacity was lost after RNase treatment indicating that RNA was the main basophilic constituent. The amount of dye bound by oocytes of the resting pool was relatively low but increased during growth reaching a peak in oocytes of about $100 \mu \mathrm{m}$ in diameter. Thereafter, there was a significant decline during progression through to ovulation. No change in dye-binding was observed between ovulation and the 1 cell embryo stage. However, there were significant declines between the 1 and 2 cell stages and between the 2 and 4 cell stages. Azur B basophilia increased again in the 8 cell embryo and was very high in the blastocyst 5 days after ovulation. These data are discussed in relation to the storage of developmental information in the oocyte and its utilization during early embryonic development.

\section{Introduction.}

The concept of maternal control of early embryogenesis has largely developed from studies of oogenesis and embryonic development in the oviparous species (Gross and Cousineau, 1964 ; Tyler, 1967). The ova of such organisms contain a store of developmental information which is utilized during the early period of growth ofter fertilization. The information is in the form of RNA which is transcribed from genes within the oocyte and accumulates during growth. All of the major RNA types are represented, the great bulk being rRNA (Davidson et al., 1964). The situation in viviparous organisms is not well defined, but there is evidence that very similar processes occur in the oocyte to control post-fertilization development. One of the important functions of the mammalian oocyte during growth is the synthesis of RNA molecules :

(1) Please address all correspondence to G.P.M. Moore. 
exogenous RNA precursors are actively incorporated (Oakberg, 1968 ; Moore et al., 1974) and endogenous nuclear RNA polymerases have been detected (Moore ef al., 1974 ; Moore and Lintern-Moore, 1978, 1979). Some of the RNA's synthesized appear to be quite stable. Bachvarova (1974) and Jahn ef al. (1976) reported that radioactive RNA precursors incorporated by growing oocytes were present in rRNA, †RNA and HnRNA at ovulation. The cytoplasm of mature ova contains both free ribosomes and polysomes (Calarco and Brown, 1969 ; Bachvarova and De Leon, 1977) as well as highly ordered lattices of RNA and proteins (Zamboni, 1970 ; Burkholder et al., 1971). At ovulation, the RNA content of the mouse oocyte has been estimated at 1.75 nanograms (ng) (Reamer, 1963) or $0.55 \mathrm{ng}$ (Olds et al., 1973) incorporating 0.2-0.4 ng of rRNA, 0.14 ng of tRNA (Young ef al., 1973 ; Bachvarova, 1974) and 0.025 ng polyadenylated RNA (Bachvarova and De Leon 1980).

The developmental events which are associated with the accumulation of RNA and its fate after oocyte maturation have not been clearly resolved. In the present study we have measured the relative amounts of RNA in the oocyte throughout the growth phase from the resting pool to ovulation and subsequently, the fate of this RNA during post-fertilization development. Total RNA was estimated cytophotometrically by measuring the amount of the basic dye Azur B bound by individual oocytes or embryos.

\section{Materials and methods.}

The mice were from a randomly bréeding colony of CFI strain animals. Oocytes at different stages of growth were obtained from juvenile and adult females. Both ovaries were removed and placed in physiological saline under a dissecting microscope. Individual oocytes and follicles were recovered by teasing the ovaries with fine needles. Adhering granulosa cells were removed by gentle pipetting or by dissection. Each oocyte was transferred to a glass slide in a small drop of saline for examination. Using a microscope fitted with an eyepiece micrometer, the mean diameter of the oocyte, including the zona pellucida, was obtained from two measurements taken at right angles to each other. The saline was then drained from the slide and the oocyte fixed in ethanol and acetone (1:1 by vol.) for $1 \mathrm{~h}$. The preparations were air dried and stored.

Oocytes from primordial follicles were obtained from newborn females. The ovaries were transferred directly to a microscope slide and teased apart. Oocytes released without adhering cells were isolated and measured and the whole preparation was fixed and stored as described above. Ovulated oocytes and embryos were obtained from females at appropriate times after mating and fixed as whole mounts. The morning on which a vaginal plug appeared was designated as day 1 of pregnancy. HnRNA.

Abbreviations : ribosomal RNA, rRNA; transfer RNA, tRNA, heterogeneous nuclear RNA, 
The preparations were stained with 0.25 p. 100 Azur B in Mcllvaine's buffer $\left(\mathrm{pH} \mathrm{4.0)}\right.$ for $2 \mathrm{~h}$ at $37^{\circ} \mathrm{C}$ following the procedure of Flax and Himes (1952). DNA was detected in the nuclei after Azur B staining by the Feulgen reaction. The acid hydrolysis step prior to reaction with Schiff reagent was effective in removing cell-bound Azur $B$. The specificity of Azur B for RNA was tested by treating oocytes, before staining, with ribonuclease $(200 \mu \mathrm{g} / \mathrm{ml}$ RNase 1, Sigma Chemical Co.) or deoxyribonuclease $\left(200 \mu \mathrm{g} / \mathrm{ml}\right.$ DNase : DN-CL Sigma, buffered at $\mathrm{pH} 6.8$ in the presence of $\left.10^{-3} \mathrm{M} \mathrm{MgCl}_{2}\right)$ for $2 \mathrm{~h}$ at $37^{\circ} \mathrm{C}$. Quantitative measurements of Azur B bound by oocytes and embryos were made with an Olympus scanning microspectrophotometer (DMSPII) at a wavelength of $540 \mathrm{~m} \mu$ (Grasso ef al., 1963). Area scans gave a measure, in arbitrary units $(\mathrm{AU})$, of the total amount of light absorbed by the stained cell components. Differences between mean absorption values at various developmental stages were tested using Student's t-test. Where sample variances were unequal, the calculation of $t$ for a significance level of 5 p. 100 was modified using the formula of Cochran and Cox (1957).

\section{Results.}

The nucleoli of oocytes stained intensely with Azur B during the growth phase, occasionally appearing as a dark central core surrounded by a zone of lesser density. By contrast, nucleoli were poorly stained or completely unstained in fully grown oocytes. After fertilization basophilic material reappeared at the peripheries of the nucleoli of 4 cell embryos. Nucleolar staining was more extensive at the 8 cell stage and the whole structure was basophilic in blastocyst cells. The cytoplasm of oocyte and embryo cells bound Azur B at all of the developmental stages examined. In blastocysts, components of the inner cell mass stained more strongly than the trophoblast.

Azur B appeared to bind specifically to RNA in these preparations. We were unable to measure any dye-binding material in RNase-treated oocytes, as this was reduced to levels which were below the threshold of sensitivity of the microspectrophotometer. No nuclear stain was observed after RNase treatment, indicating that DNA did not contribute significantly to Azur B basophilia in oocytes. The presence of DNA in the nuclei of RNase-treated cells was confirmed using the Feulgen reaction after staining with Azur B.

Measurements of the relative amounts of Azur B bound by oocytes and embryos during development are depicted in figure 1. Light absorption was relatively low in small, resting oocytes, but increased during growth, reaching a peak in oocytes of about $100 \mu \mathrm{m}$ in diameter. A significant decline was observed between this stage and ovulation $\left(t_{21}=2.06, p<0.05\right)$. The amount of Azur B bound by unfertilized ova obtained from the fallopian tubes of one mouse on the second day after mating was significantly less than that of ova which had been collected on the day of ovulation (mean absorption, day 1 ova : $48.0 \pm 3.7$; day 2 ova : $36.1 \pm 0.9, t_{10}=3.11, p<0.05$ ).

The amount of dye bound by the ovulated ovum was not altered after fertilization, before the first cleavage division. Thereafter, there was a decline both between the 1 and 2 cell stages and between the 2 and 4 cell stages. Basophilia increased again in the 8 cell embryo and was very high in the blastocyst 5 days after fertilization. 


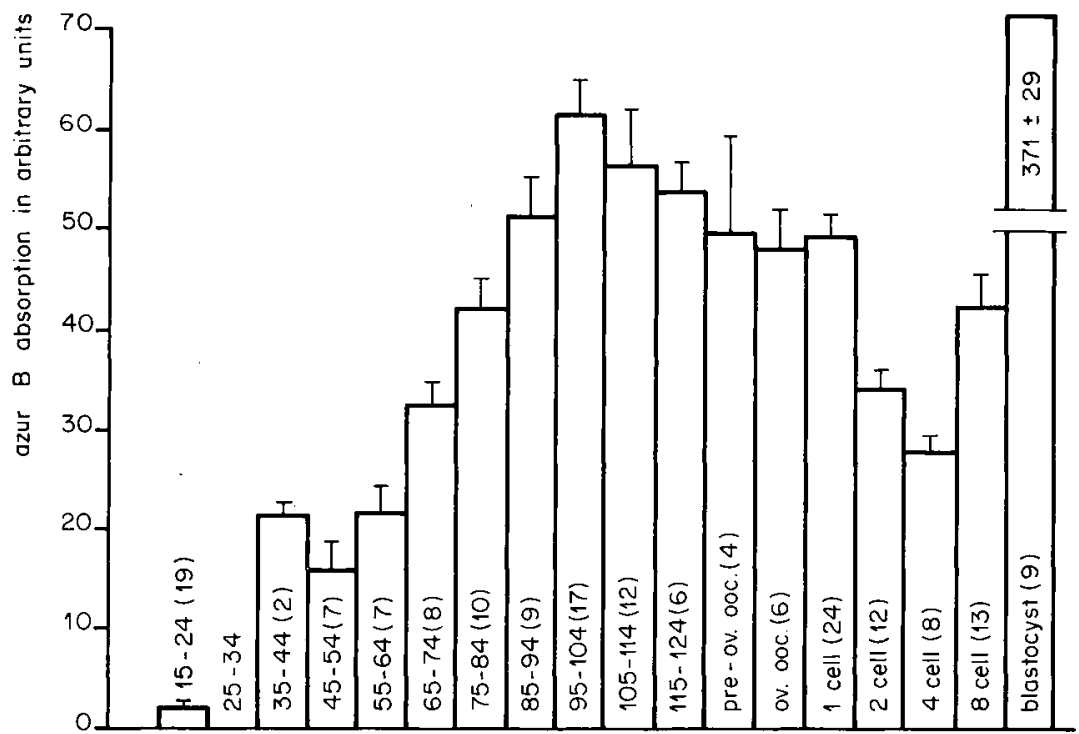

FIG. 1. - Relative changes in total light absorption by Azur B stained oocytes and embryos, mean $\pm S E M$. Abbreviations : pre-ov. ooc.-preovulatory oocyte showing chromosome condensation ; ov. ooc.ovulated oocyte. Oocyte diameter in $\mu \mathrm{m}: 15-24$ to 115-124. Figures in parentheses refer to the number of oocytes or embryos measured at each stage.

\section{Discussion.}

Components of the nucleus and cytoplasm of mouse oocytes and embryos bind the basophilic dye Azur B. The staining material of oocytes was removed by prior treatment with RNase indicating that under the conditions used here, RNA was the major dye-binding constituent (see also Shea, 1970). Our data for oocytes are consistent with the study of Flax (1953) which demonstrated a close correspondence between Azur B and ultraviolet absorption measurements of the oocyte cytoplasm during growth. We have measured whole cell basophilia since the nucleus may contain a considerable amount of chromosomal RNA. The relative amounts of Azur B bound by embryos, when compared with that of the ovulated egg, parallel the changes in absolute amounts of RNA estimated biochemically by Olds et al. (1973) (table 1).

The present study shows that oocytes of the mouse progressively accumulate RNA during development. Based on observations of other species this maternal RNA would constitute a store of developmental molecules for early embryo development. The progressive decline in RNA content between the 1, 2 and 4 cell embryo stages (fig.1), is consistent with the view that stored RNAs are being utilized during the initial phase of early cleavage development (see also Bachvarova and De Leon 1980).

The significance of the contribution of RNA from the embryo genome to development is not known. Clearly, the amount of newly synthesized RNA produced during 
TABLE 1

Chemical estimotes of total RNA in the ovulated ovum and embryos compared with microspectrophotometric determinations of Azur B basophilia during similar developmental stages

\begin{tabular}{|c|c|c|c|c|}
\hline \multirow[b]{2}{*}{ Stage } & \multicolumn{2}{|c|}{ Mean RNA content $\left({ }^{1}\right)$} & \multicolumn{2}{|c|}{ Azur B absorption } \\
\hline & ng & $\begin{array}{c}\text { P. } 100 \\
\text { of unf. ovum }\end{array}$ & A.U. $\left({ }^{2}\right)$ & $\begin{array}{c}\text { P. } 100 \\
\text { of unf. ovum }\end{array}$ \\
\hline $\begin{array}{l}\text { Ovulated ovum } \ldots \ldots \ldots \\
1 \text { cell embryo } \ldots \ldots \ldots \\
2 \text { cell embryo } \ldots \ldots \ldots \\
4 \text { cell embryo } \ldots \ldots \ldots \\
8-9 \text { cell embryo } \ldots \ldots \ldots \\
\text { Early blastocyst }\left({ }^{3}\right) \ldots \ldots \\
\text { Late blastocyst }\left({ }^{4}\right) \ldots \ldots\end{array}$ & $\begin{array}{l}0.554 \\
0.545 \\
0.396 \\
\overline{-} \\
0.458 \\
1.37 \\
-\end{array}$ & $\begin{array}{r}100 \\
98 \\
71 \\
83 \\
247 \\
-\end{array}$ & $\begin{array}{l}48.0 \\
49.0 \\
33.8 \\
27.8 \\
42.1 \\
370.8\end{array}$ & $\begin{array}{r}100 \\
102 \\
70 \\
58 \\
88 \\
773\end{array}$ \\
\hline
\end{tabular}
57.4.

$\left({ }^{1}\right)$ data from Olds et al. $(1973) ;\left({ }^{2}\right)$ arbitrary units ; $\left({ }^{3}\right)$ mean no. cells : $33.7 ;\left({ }^{4}\right)$ mean no. cells :

the period of the first two cleavage divisions is not sufficient to replace that which has been lost. In the mouse it is possible that RNA is synthesized at the 1 cell stage although the evidence is conflicting (Mintz, 1964 ; Knowland and Graham, 1972 ; Moore, 1975 ; Clegg and Piko, 1977 ; Young et al., 1978). However, RNA synthesis has been demonstrated in the 2 cell embryo and appears to be predominantly of a heterogeneous type (Knowland and Graham, 1972). Nucleoplasmic RNA polymerases which are sensitive to $\alpha$-amanitin have been found to be active at this stage (Moore, 1975). If transcription is initiated at this stage, then maternal RNA must be solely responsible for the production of new proteins, at least prior to the first cleavage division.

The precise stage at which rRNA synthesis resumes in the mouse embryo has not been resolved. Mintz (1964) demonstrated nucleolar incorporation of ${ }^{3} \mathrm{H}$-uridine in 4 cell embryos. Subsequently, Knowland and Graham (1972) reported the presence of extremely small amounts of newly labelled rRNA at the 2 cell stage (see also Hillman and Tasca 1969). In the present study the appearance of basophilic material was first observed at the peripheries of the nucleoli of 4 cell embryos (see also Alfert, 1950 ; Flax, 1953). We have previously demonstrated that it was precisely at this location that the activities of the $\alpha$-amanitin-resistant, type I RNA polymerases reappeared (Moore, 1975). A clue to the resolution of this discrepancy may lie in an observation by Mintz (1964) that the nucleoli of 2 cell embryos would incorporate ${ }^{3} \mathrm{H}$-uridine if the next cleavage was delayed. This suggests that reactivation of the nucleolar genes may not be linked with a particular stage of cleavage but rather that development is temporally dependent on ribosome production (Liebhaber et al., 1978).

The increase of Azur B basophilia at the 8 cell stage probably resulted from the restoration of rRNA synthesis at the 4 cell stage and the addition of new ribosomes to the depleted, maternally-derived stock. Brinster (1971) observed that uptake and incorporation of amino acids also increased in the mouse embryo at the 8 cell stage, suggesting that protein synthesis in the embryo may have been limited by the cyto- 
plasmic ribosome population. Thereafter, between the 8 cell and blastocyst stages, both Azur B basophilia and the synthesis of all major RNA species increase (Monesi and Salfi, 1967 ; Ellem and Gwatkin, 1968 ; Daentl and Epstein, 1971).

The data obtained for day 2 unfertilized ova provide an additional insight into the fate of maternal RNA after ovulation. The amount of Azur B bound by these ova $(36.1 \pm 0.9$ units) was similar to that of 2 cell embryos of the same age ( $33.8 \pm 1.6$ units), indicating that RNAs which remained stable during the long period of oocyte growth were utilized for the synthesis of proteins at some stage alter ovulation. Protein synthesis has been detected in unfertilized mouse ova (Brinster, 1971) and remains at a relatively constant level between ovulation and the 2 cell embryo stage (Brinster ef al., 1976). Furthermore, the pattern of proteins synthesized does not after immediately after fertilization (Schultz ef al., 1979), suggesting that the programme for development which has been stored in the form of RNA molecules in the oocyte is initiated before fertilization and proceeds whether or not fertilization takes place.

Reçu en septembre 1980.

Accepté en février 1981.

Acknowledgements. - We thank Professor A. Datyner and Dr M. Pailthorpe for making the Olympus DMSPII microspectrophotometer of the School of Textile Technology, University of New South Wales, available for our study. Effie Howe and Roslyn Hawkins provided expert technical assistance.

Résumé. On a utilisé la cyłophotométrie quantitative pour suivre les changements de la basophilie à l'Azur B, d'ovocytes isolés et d'embryons de Souris au stade préimplantatoire. Les composants du noyau et du cytoplasme lient l'Azur B, mais la plus grande partie de leur capacité de liaison au colorant se perd après traitement par la RNase, ce qui indique que I'ARN est le constituant le plus basophile. La quantité de colorant liée par les ovocytes du pool de réserve est relativement faible, mais augmente durant leur croissance et atteint un pic pour les ovocytes de $100 \mu \mathrm{m}$ de diamètre ; ensuite elle diminue significativement lorsqu'on va vers l'ovulation. On n'a pas observé de changement dans la liaison au colorant entre l'ovulation et le stade 1 cellule, mais elle diminue significativement entre les stades 1 et 2 cellules et entre les stades 2 et 4 cellules. La basophilie à l'Azur B augmente à nouveau chez l'embryon au stade 8 cellules et est très élevée chez le blastocyste 5 jours après l'ovulation. Ces résultats sont discutés dans le cadre du stockage dans l'ovocyte, des informations relatives au développement et de leur utilisation durant le développement embryonnaire précoce.

\section{References}

ALFERT M., 1950. A cytochemical study of oogenesis and cleavage in the mouse. J. Cell comp. Physiol., 36, 381-409.

BACHVAROVA R., 1974. Incorporation of tritiated adenosine into mouse ovum RNA. Devel. Biol., 40, 52-58.

BACHVAROVA R., De LEON V., 1977. Stored and polysomal ribosomes of mouse ova. Devel. Biol., 58, 248-254.

BACHVAROVA R., De LEON V., 1980. Polyadenylated RNA of mouse ova and loss of maternal RNA in early development. Devel. Biol., 74, 1-8. 
BRINSTER R. L., 1971. Uptake and incorporation of amino acids by the preimplantation mouse embryo. J. Reprod. Fert., 27, 329-338.

BRINSTER R. L., WIEBOLD J. L., BRUNNER S., 1976. Protein metabolism in preimplanted mouse ova. Devel. Biol., 51, 215-224.

BURKHOLDER G. D., COMINGS D. E., OKADA T. A., 1971. A storage form of ribosomes in mouse oocytes. Exp. Cell Res., 69, 361-371.

CALARCO P. G., BROWN E. H., 1969. An ultrastructural and cytological study of preimplantation development of the mouse. J. exp. Zool., 171, 253-284.

CLEGG K. B., PIKO L., 1977. Size and specific activity of the UTP pool and overall rates of RNA synthesis in early mouse embryos. Devel. Biol., 58, 76-95.

COCHRAN W. G., COX G. M., 1957. Experimental designs. J. Wiley, New York.

DAENTL D. L., EPSTEIN C. J., 1971. Developmental interrelationships of uridine uptake, nucleotide formation and incorporation into RNA by early mammalian embryos. Devel. Biol., 24, 428-442.

DAVIDSON E. H., ALLFREY V. G., MIRSKY A. E., 1964. On the RNA synthesized during the lampbrush phase of amphibian oogenesis. Proc. nat. Acad. Sci. U.S.A., 52, 501-508.

ELLEM K. A. O., GWATKIN R. B. L., 1968. Patterns of nucleic acid synthesis in the early mouse embryo. Devel. Biol., 18, 311-330.

FLAX M. H., 1953. Ribose nucleic acid and protein during oogenesis and early embryonic development in the mouse. Ph. D. Thes., Columbia Univ.

FLAX M. H., HIMES M. H., 1952. Microspectrophotometric analysis of metachromatic staining of nucleic acids. Physiol. Zool., 25, 297-311.

GRASSO J. A., WOODARD J. W., SWIFT H., 1963. Cytochemical studies of nucleic acids and proteins in erythrocyte development. Proc. nat. Acad. Sci. U.S.A., 50, 134-140.

GROSS P. R., COUSINEAU G. H., 1964. Macromolecule synthesis and the influence of actinomycin on early development. Exp. Cell Res., 33, 368-395.

HILLMAN N., TASCA R. J., 1969. Ultrastructural and autoradiographic studies of mouse cleavage stages. Am. J. Anat., 126, 151-174.

JAHN C. L., BARAN M. M., BACHVAROVA R., 1976. Stability of RNA synthesized by the mouse oocyte during its growth phase. J. exp. Zool., 197, 161-172.

KNOWLAND J., GRAHAM C., 1972. RNA synthesis at the two-cell stage of mouse development. J. Embryol, exp. Morph., 27, 167-178.

LIEBHABER S. A., WOLF S., SCHLESSINGER D., 1978. Differences in rRNA metabolism of primary and SV40-transformed human fibroblasts. Cell, 13, 121-127.

MINTZ B., 1964. Synthetic processes and early development in the mammalian egg. J. exp. Zool., 157, 85-100.

MONESI V., SALFI V., 1969. Macromolecular syntheses during early development in the mouse embryo. Exp. Cell Res., 46, 632-635.

MOORE G. P. M., 1975. The RNA polymerase activity of the preimplantation mouse embryo. J. Embrol. exp. Morph., 34, 291-298.

MOORE G. P. M., LINTERN-MOORE S., 1978. Transcription of the mouse oocyte genome. Biol. Reprod., 17, 865-870.

MOORE G. P. M., LINTERN-MOORE S., 1979. Stimulation of endogenous RNA polymerase I activity in the mouse oocyte after PMSG treatment. Biol. Reprod., 21, 373-377.

MOORE G. P. M., LINTERN-MOORE S. M., PETERS H., FABER M., 1974. RNA synthesis in the mouse oocyte. J. Cell Biol., 60, 416-422.

OAKBERG E. F., 1968. Relationship between stage of follicular development and RNA synthesis in the mouse oocyte. Mutation Res., 6, 155-165.

OLDS P. J., STERN S., BIGGERS J. D., 1973. Chemical estimates of the RNA and DNA contents of the early mouse embryo. J. exp. Zool., 186, 39-46.

REAMER G. R., 1963. The quantify and distribution of nucleic ocids in the early cleavage stages of the mouse embryo. Ph. D. Thes., Boston Univ.

SCHULTZ R. M., LETOURNEAU G. E., WASSARMAN P. M., 1979. Programme of early development in the mammal : Changes in patterns and absolute rates of fubulin and total protein synthesis during oogenesis and early embryogenesis in the mouse. Devel. Biol., 68, 341-359.

SHEA J. R., 1970. A method for in situ cytophotometric estimation of absolute amount of ribonucleic acid using Azur B. J. Histochem. Cytochem., 18, 143-152. 
TYLER A., 1967. Masked messenger RNA and cyloplasmic DNA in relation to protein synthesis and processes of fertilization and determination in embryonic development. Devel. Biol., Suppl. 1, 170-226.

YOUNG R. J., STULL G. B., BRINSTER R. C., 1973. RNA in mouse ovulated oocyies. J. Cell Biol., 59, $372 a$.

YOUNG R. J., SWEENEY K., BEDFORD J. M., 1978. Uridine and guanosine incorporation by the mouse one-cell embryo. J. Embryol. exp. Morph., 44, 133-148.

ZAMBONI L., 1970. Ultrastructure of mammalian oocytes and ova. Biol. Reprod., Suppl. 2, 44-63. 